\title{
Hematological and histo-architectural damages in the kidney and liver of Nile tilapia on exposure to kinalux
}

\author{
MTA Nannu, GM Mostakim¹, MH Khatun ${ }^{1}$, MK Rahman², MI Sadiqul ${ }^{1}$ * \\ ${ }^{1}$ Department of Fisheries Biology and Genetics, Bangladesh Agricultural University, Mymensingh-2202, \\ Bangladesh; ${ }^{2}$ Freshwater Station, Bangladesh Fisheries Research Institute
}

Mymensingh-2201, Bangladesh

\begin{abstract}
Study was conducted to assess the histo-architectural damages of kidney and liver and hematological parameters in Nile tilapia (Oreochromis niloticus) after sub-lethal exposure to kinalux. Fish was exposed to two sub-lethal concentrations ( $10 \%$ and 50\%, 0.052 and $0.259 \mathrm{ppm}$ of median lethal concentration, respectively) of kinalux for 90 days and a parallel control was run simultaneously. Kidney and liver of exposed individuals exhibited some remarkable changes in their histology in comparison to control. Significant changes also occurred in the number of red blood cell (RBC) and white blood cell (WBC). Duration of exposure appears to have a profound effect on kidney and liver as with increasing duration of exposure histo-architectural damages become more severe.
\end{abstract}

Key words: Hematology, histopathology, kinalux 25EC, Oreochromis niloticus, organophosphate pesticide

Progressive Agriculturists. All rights reserve

*Corresponding Author: sadiqul1973@yahoo.com

\section{Introduction}

Pesticides have been widely used all over the world to control insects, pests and disease vectors and they are one of the most potentially harmful chemicals introduced into the environment, though they have contributed considerably to human welfare, their adverse effects on non-target organisms are significant (Velisek et al., 2009). These pesticides ultimately find their way into aquatic habitats such as rivers, lakes and ponds, and have been found to be highly toxic not only to fish but also to the organisms, which constitute the food chain (Arjmandi et al., 2010). Sometimes this pollution may cause sudden death of fish and other aquatic organisms.

Kinalux is an organophosphate pesticide and it is an extensively used pesticide in our area. Extensive use of organophosphate compounds has resulted in a wide spread distribution of these chemicals in the environment. They are much less persistent than the organochlorines and do not accumulate in fatty tissues. Due to their rapid biodegradability and lesser persistency in the environment, the organophosphate compounds replaced the more persistent organochlorine compounds. Organophosphorous pesticides to a large extent replaced the persistent chlorinated pesticides in the 1970s and at the beginning of 1980s. The main advantage of the organophosphate is their low cumulative ability and short-term persistence in the environment (Özcan et al., 2006). These pesticides leave residues in the soil and water for several days after their application, and pose a constant threat to the non-target organisms especially fishes (Magare and Patil, 2000). Therefore, the usage of organophosphate pesticides has an impact on environment leading to the development of several adaptations such as morphological, physiological, biochemical and 


\section{Damages in kidney and liver of Nile tilapia}

behavioral ones at various levels of organization in the organisms to suit their environment.

Histopathological changes have been widely used as biomarkers in the evaluation of the health of fish exposed to contaminants, both in the laboratory (Thophon et al., 2003) and field studies (Schwaiger et al., 1997). One of the great advantages of using histopathological biomarkers in environmental monitoring is that this category of biomarkers allows examining specific target organs, including gills and liver that are responsible for vital functions, such as respiration, excretion and accumulation and biotransformation of xenobiotics in the fish, and serve as warning signs of damage to animal health (Gernhofer et al., 2001). The present study was performed to evaluate the sub-lethal effects of kinalux on histopathological alterations in the vital organs like kidney and liver and hematological changes of Nile tilapia, Oreochromis niloticus as a laboratory animal model. The Nile tilapia was selected for the bioassay experiments since it is one of the most economically important freshwater fish that is extensively cultured in Bangladesh, India, Philippines, Vietnam, and many other countries.

\section{Materials and Methods}

Kinalux 25EC toxicity was assessed using tilapia as an aquaculture model in this experiment. Two hundred live and healthy tilapia (Oreochromis niloticus) purchased from local fish farm of Mymensingh. Standard length and average body weight of the experimental fish were $6.21 \pm 0.67 \mathrm{~cm}$ and $4.17 \pm 1.46 \mathrm{~g}$, respectively and allowed to acclimatize to the laboratory conditions for two weeks before experiment.

Kinalux 25EC was purchased from the authorized dealer of Mymensingh. Ten fishes were randomly selected from the stock and exposed to different concentrations of kinalux (0.3, 0.4, 0.7, 0.8, 1.0 ppm) for 96 hours to determine the median lethal concentration $\left(\mathrm{LC}_{50}\right)$. Water was replaced daily with fresh kinalux mixed water to maintain constant level of kinalux during exposure period. The $\mathrm{LC}_{50}$ value for kinalux was $0.518 \mathrm{ppm}$. Based on the result of the 96h $\mathrm{LC}_{50}$ of kinalux, 100 fishes of Nile tilapia were exposed for 90 days to the sub-lethal concentrations of $10 \%$ and $50 \%$ value of the $\mathrm{LC}_{50}$ of the kinalux. A control group was maintained simultaneously. All these experiments were performed in triplicates.

For hematological and histological studies, three fishes were removed from each treatment including control at fifteen days interval up to the end of 90 days exposure period. They were randomly selected from each group and immediately sacrificed by pinning through the brain and samples like blood, liver and kidney were collected from the dissected fishes. Blood samples were used to measure red blood cell count and white blood cell count (RBC and WBC) which was done immediately. RBC and WBC counts were carried out in a Neubauer chamber after saline $(0.9 \% \mathrm{NaCl}$ solution) dilution of the blood. For the histological study specimens were preserved in $10 \%$ formalin and histological examination was done using standard histological technique. All data obtained in test was analyzed using probit method and one way analysis of variance (ANOVA) followed by post-hoc testing using Duncan mean, performed with SPSS version 16. The data are presented as mean \pm standard deviation of the means.

\section{Results}

No fish died during the acclimation period before kinalux exposure, and no control fish died during toxicity tests. The probit analysis showed that the lethal concentration for $50 \%$ mortality of the fishes at 96h was $0.52 \mathrm{ppm}$. In the present study, exposure of fish to sub-lethal concentrations of kinalux (0.052 and $0.259 \mathrm{ppm}$ ) for 90 days caused significant alterations in hematological parameters (Table 1). The alterations observed in hematological parameters such as red blood cell, RBC values were decreased significantly up to 45 days of exposure and white blood cell, WBC values increased significantly after 90 days of exposure periods, respectively, in comparison with control. Furthermore, dose dependent variations were depicted in the hematological parameters of the kinalux treated fishes.

Kidney tubules and hematopoietic cells were normal and systematically arranged in the control treatment. Kinalux exposed kidney sections showed 
disintegration of convoluted tubules with large intracytoplasmic vacuoles in the epithelial cells and lumen. Shrinkage and degeneration of the glomeruli, dilation within the Bowman's space were also recorded (Figure $1 \mathrm{~A}-\mathrm{G}$ ).

The haepatocytes and other cells of the liver in control treatment were normal and systematically arranged. The liver of the kinalux exposed fishes showed changes including degeneration of cytoplasm in hepatocytes, rupture in blood vessels and disappearance of cell boundaries result in releasing of blood causes hemorrhage, leading to the centrolobular degeneration. Dead red blood cells were also seen in necrotic area (Figure $2 \mathrm{~A}-\mathrm{G}$ ).

Table 1. Mean Red Blood Cell (RBC) \& White Blood cell (WBC) of tilapia exposed at 0, 0.052 and 0.259 ppm concentrations of kinalux at different days.

\begin{tabular}{|c|c|c|c|c|c|c|c|}
\hline \multirow{2}{*}{ Parameters } & \multirow{2}{*}{ Treatments } & \multicolumn{7}{|c|}{ Exposure time (days) } \\
\cline { 2 - 8 } & & $\mathbf{1 5}$ & $\mathbf{3 0}$ & $\mathbf{4 5}$ & $\mathbf{6 0}$ & $\mathbf{7 5}$ & $\mathbf{9 0}$ \\
\hline \multirow{2}{*}{$\begin{array}{c}\mathrm{RBCs} \\
\left(\mathrm{x} 10^{6} / \mathrm{mm}^{3}\right)\end{array}$} & $0 \mathrm{ppm}$ & $1.46 \pm 0.055^{\mathrm{a}}$ & $1.91 \pm 0.051^{\mathrm{a}}$ & $1.89 \pm 0.035^{\mathrm{a}}$ & $2.31 \pm 0.032^{\mathrm{a}}$ & $2.7 \pm 0.035^{\mathrm{a}}$ & $3.01 \pm 0.094^{\mathrm{a}}$ \\
\cline { 2 - 8 } & $0.052 \mathrm{ppm}$ & $1.35 \pm 0.031^{\mathrm{b}}$ & $1.46 \pm 0.025^{\mathrm{b}}$ & $1.29 \pm 0.025^{\mathrm{b}}$ & $1.95 \pm 0.041^{\mathrm{b}}$ & $1.59 \pm 0.050^{\mathrm{b}}$ & $2.80 \pm 0.058^{\mathrm{b}}$ \\
\cline { 2 - 8 } & $0.259 \mathrm{ppm}$ & $1.25 \pm 0.050^{\mathrm{b}}$ & $1.18 \pm 0.031^{\mathrm{c}}$ & $1.18 \pm 0.026^{\mathrm{c}}$ & $1.86 \pm 0.040^{\mathrm{b}}$ & $1.63 \pm 0.045^{\mathrm{c}}$ & $2.73 \pm 0.030^{\mathrm{b}}$ \\
\hline \multirow{2}{*}{$\begin{array}{c}\text { WBCs } \\
\left(\times 10^{4} / \mathrm{mm}^{3}\right)\end{array}$} & $0 \mathrm{ppm}$ & $2.13 \pm 0.252^{\mathrm{a}}$ & $1.59 \pm 0.074^{\mathrm{a}}$ & $1.92 \pm 0.038^{\mathrm{a}}$ & $1.85 \pm 0.040^{\mathrm{a}}$ & $2.11 \pm 0.096^{\mathrm{a}}$ & $2.63 \pm 0.076^{\mathrm{a}}$ \\
\cline { 2 - 8 } & $0.052 \mathrm{ppm}$ & $2.88 \pm 0.091^{\mathrm{b}}$ & $2.84 \pm 0.061^{\mathrm{b}}$ & $2.75 \pm 0.107^{\mathrm{b}}$ & $2.70 \pm 0.106^{\mathrm{b}}$ & $2.67 \pm 0.051^{\mathrm{b}}$ & $2.71 \pm 0.87^{\mathrm{a}}$ \\
\cline { 2 - 8 } & $0.259 \mathrm{ppm}$ & $3.17 \pm 0.246^{\mathrm{c}}$ & $3.10 \pm 0.215^{\mathrm{b}}$ & $3.18 \pm 0.124^{\mathrm{c}}$ & $2.77 \pm 0.122^{\mathrm{b}}$ & $2.75 \pm 0.072^{\mathrm{b}}$ & $2.79 \pm 0.099^{\mathrm{c}}$ \\
\hline
\end{tabular}

Values are mean \pm standard deviation, different alphabetic superscripts $a, b, c$ indicates significant differences at $p<0.05$ level.

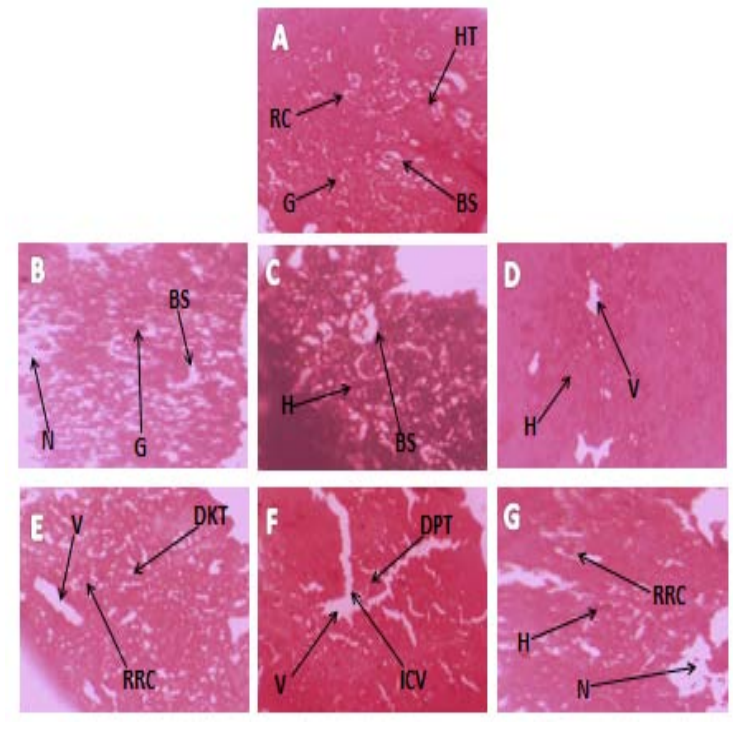

Figure 1. Histoarchitectural changes in kidney (H \& E stained, X100) exposed to Kinalux (A) 0 ppm, (B), (C) and (D) at $0.052 \mathrm{ppm}$; (E) and $(\mathrm{F})$ and $(\mathrm{G})$ at $0.259 \mathrm{ppm}$ at 30,60 and 90 days. Arrows are indicating RC-Renal corpuscle, G-Glomeruli, HTHaepatopoietic tissue, BS-Bowman's space, N-Necrosis, DKT-Degenerated kidney tissue, V-Vacuolation, RRCRuptured renal corpuscle, DHTDegenerated haepatopoietic tissue, ICVIntra-cytoplasmic vacuoles, H-Hemorrhage
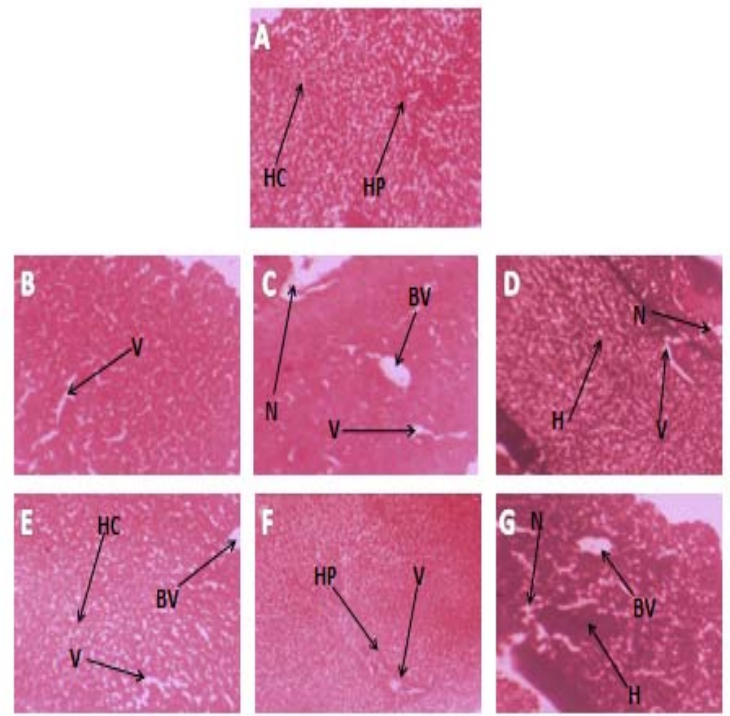

Figure 2. Histoarchitectural changes in liver ( $\mathrm{H}$ \& $\mathrm{E}$ stained, X100) exposed to Kinalux (A) Control, (B), (C) and (D) at $0.052 \mathrm{ppm}$; (E) and $(\mathrm{F})$ and $(\mathrm{G})$ at $0.259 \mathrm{ppm}$ at 30,60 and 90 days respectively. Arrows are indicating HC - Haepatic cell, HP - Haepatopancreas, V - Vacuoles, H - Hemorrhage, $\mathrm{BV}$ - Blood vessel, $\mathrm{N}$ - Necrosis 


\section{Discussion}

The present study revealed that an organophosphate pesticide, kinalux exposure induced histoarchitectural alterations in kidney and liver and hematological parameters of Nile tilapia, severity of the alterations were dose and duration dependent. The exposure of aquatic organisms to sub-lethal concentration of pesticides in their environment may result in various biochemicals, physiological and histological alterations in vital tissues (Geraldine et al., 1999).

Insecticides may lead to alterations in the blood parameters and hematological profile of fish which can be investigated as biomarker in pollution monitoring (Banaee et al., 2008). The present study shows significant decrease in RBC count following exposure to kinalux that might be due to hemolysis and shrinkage of hematopoietic blood cells by the toxic effect of pesticide. The increase rate of RBC breakdown or reduction rate of RBC formation might also be responsible for reduction in RBC count. While correlating with the histopathological changes, the destruction of the hematopoietic tissue in the head kidney was evident might be responsible for decrease in RBC (Das, 1998). The reduction number of erythrocytes suggested hypoxic effect prevailing over the body tissues of the fingerlings due to damaging effect on the gill tissue. Reduction in number of erythrocytes reported in this investigation indicated that $O$. niloticus exposed to sub-lethal concentrations of kinalux became anemic, which is similar to the findings of Wedemeyer et al. (1984). A reduction in the erythrocytes number of Atlaltic salmon (Salmo salar) and channel catfish (Ictalurus punctatus) exposed to malachite green were also reported by Glagoleva and Malikova (1968) and there also was a reduction in erythrocytes number in Nile tilapia exposed to gammalin 20 and actellic 25EC by Omoregie et al. (1990).

In this study a significant increase in the WBC count was observed in fish exposed to sub-lethal dosages in 90 days. In the presence of foreign substances or under pathological conditions leucocytosis in fish may be the consequence of direct stimulation of immunological defense (John, 2007). As leukocytes fight against any toxicant introduced into the blood stream, this increase suggests that fish has developed a certain degree of tolerance by stages during the stress conditions. The increase in WBC count can be correlated with an increase in antibody production which helps in survival and recovery of the fish exposed to lindane and malathion (Joshi et al., 2002). This also helps in the removal of cellular debris of necrosed tissue at a faster rate (John, 2007). Consistent supports to the above several results showed a significant increase in the WBC (Adedeji et al., 2009; Kumar et al., 2011; Saravanan et al., 2011).

In sub-lethal dosages of kinalux several alterations such as degeneration of kidney tubules and hematopoietic tissue, vacuolization, mild to severe necrosis, pyknosis and hemorrhage were recorded. Shrinkage and degeneration of the glomeruli, dilation within the Bowman's space were also seen. Similar to the present findings necrosis, pyknosis, hemorrhages, vacuolation, degeneration of kidney tubules and hematopoietic cells were reported on Anabas testudineus, Channa punctatus and Barbodes gonionotus at $3.75 \mathrm{ppm}, 2.26 \mathrm{ppm}$ and $2.26 \mathrm{ppm}$, of diazinon 60EC, respectively for 7 days by Rahman $e t$ al. (2002).

Fish liver histopathology is an indicator of chemical toxicity and it is a useful way to study the effects of exposure of aquatic animals to toxins present in the aquatic environment (Fernandes et al., 2008). In the present study, histo-architectural changes of liver were observed after exposure to the kinalux such as hypertrophy of hepatocytes, mild to severe necrosis, blood spilling, ruptured central vein, lipid droplet and vacuolation. The recorded results in the present study were similar to those observed by Kunjamma et al. (2008) recorded pyknotic nucleus, protein precipitation, pancreatic acini appeared with the loss normal structure and necrosis of the hepatic and pancreatic tissue in freshwater fish (Catla catla) and (Oreochromis mossambicus) treated with chlorpyrifos.

\section{Conclusion}

The results of the present investigation reveal that under experimental condition, hematological 


\section{Damages in kidney and liver of Nile tilapia}

parameters and some organs of tilapia were sensitive to kinalux exposure. These findings permit us to conclude that kinalux is highly toxic to fish. Hence, the presence of kinalux in waterways could have adverse impact on the survival of the fish. Therefore it is necessary to monitor, the level of kinalux in aquatic environments.

\section{Acknowledgement}

This work was supported by a grant IADCAEPP provided by Bangladesh Fisheries Research Institute (BFRI), Mymensingh-2201, Bangladesh.

\section{References}

Adedeji OB, Adedeji OA, Adeyemo OK, Agbeda SA (2009). Acute effects of diazinon on blood parameters in the African catfish (Clarias gariepinus). Internet Journal of Hematology, 5(2):708-715.

Arjmandi R, Tavakol M, Shayeghi M (2010). Determination of organophosphorus insecticide residues in the rice paddies. International Journal Environmental Science Technology, 7(1):175-182.

Banaee M, Mirvagefei AR, Rafei GR, MajaziAmiri B (2008). Effect of sub-lethal diazinon concentrations on blood plasma biochemistry. International Journal of Environmental Resources, 2(2):189-198.

Das BK (1998). Studies on the effect of some pesticides and commonly used chemicals on Indian major carps and their ecosystem.D. Phil Thesis, 139-162. Orissa University of Agriculture and Technology, Bhubaneswar (India).

Fernandes C, Fontainhas-Fernandes A, Rocha E, Salgado MA (2008). Monitoring pollution in Esmoriz-Paramos lagoon, Portugal: liver histological and biochemical effects in Liza saliens. Environmental Monitoring and Assessment, 145:315-22.

Geraldine P, Bhavan PS, Kaliamurthy J, Zayapragassarazan Z (1999). Effects of dichlorvos intoxication in the freshwater prawn Macrobrachium malcolmsonii. Journal of Environmental Biology, 20:141-8.
Gernhofer M, Pawet M, Schramm M, Muller E, Triebskorn R (2001). Ultrastructural biomarkers as tools to characterize the health status of fish in contaminated streams. Journal of Aquatic Ecosystem Stress and Recovery, 8:241-260.

Glagoleva TP, Malikova EM (1968). The effects of malachite green on the blood composition of young Baltic salmon. Rybone Khozyaistro, 44:15-18.

John PJ (2007). Alteration of certain blood parameters of freshwater teleost, Mystus vittatus after chronic exposure to metasystox and sevin. Fish Physiology and Biochemistry, 33(1):15-20.

Joshi PK, Harish D, Bose M (2002). Effect of lindane and malathione exposure to certain blood parameters in a fresh water teleost fish, Clarias batrachus. Pollution Resources, 21(1):55-57.

Kumar N, Prabhu PAJ, Pal AK, Remya S, Aklakur M, Rana RS, Gupta S, Raman RP, Jadhao SB (2011). Anti-oxidative and immunohematological status of tilapia Oreochromis mossambicus during acute toxicity test of endosulfan. Pesticide Biochemistry and Physiology, 99:45-52.

Kunjamma A, Philip B, Bhanu S, Jose J (2008). Histopathological effects on Oreochromis mossambicus (Tilapia) exposed to chlorpyrifos. Journal of Environmental Research and Development, 2(4):553-559.

Magare SR, Patil HT (2000). Effect of pesticides on oxygen consumption. Red blood cell count and metabolites of fish, Puntius ticto. Journal of Environment and Ecology, 18(4):891-894.

Omoregie E, Ufodike EBC, Keke (1990). Tissue chemistry of Oreochromis niloticus exposed to sub-lethal concentrations of gammalin 20 and actellic 25 EC. Journal of Aquatic Sciences, 5:33-36

Özcan Oruc E, Üner N, Sevgiler Y, Usta D, Drumaz $H$ (2006). Sublethal effects of organophosphate diazinon on the brain of Cyprinus Carpio. Drug and Chemical Toxcology, 29:57-67.

Rahman MZ, Hossain Z, Mollah MFA, Ahmed GU (2002). Effects of diazinon 60EC on Anabas 
testudineus, Channa punctatus, and Barbodes gonionotus. Naga.The ICLARM Quarterly, 25:8-11.

Saravanan M, Prabhu K, Ramesh M (2011). Hematological and biochemical responses of freshwater teleost fish Cyprinus carpio (Actinopterygii: Cypriniformes) during acute and chronic sub-lethal exposure to lindane. Pesticide Biochemistry and Physiology, 100(3):206-211.

Schwaiger J, Wanke R, Adam S, Pawert M, Honnen W, Triebskorn R (1997). The use of histopatological indicators to evaluate contaminant-related stress in fish. Journal of Aquatic Ecosystem Stress and Recovery, 6:7586.

Thophon S, Kruatrachue M, Upathan ES, Pokethitiyook P, Sahaphong S, Jarikhuan S
(2003). Histopathological alterations of white seabass, Lates calcarifer in acute and subchronic cadmium exposure. Environmental Pollution, 121:307-320.

Velisek J, Svobodova Z, Piackova V (2009). Effects of acute exposure to bifenthrin on some haematological, biochemical and histopathological parameters of rainbow trout (Oncorhynchus mykiss). Journal of Veterinary Medicine, 54(3):131-137.

Wedemeyer GA, McLeay DJ, Goodyear CP (1984). Assessing the tolerance of fish and fish populations to environmental stress. The problems and methods of monitoring. In: Contaminant effects on fisheries (Eds: Cairns VW, odson PY, Nriagu JO) John Wiley and Sons, New York, pp 164-195. 